\title{
Fiber and Lignin Analysis in Concentrate, Forage, and Feces: Detergent Versus Enzymatic-Chemical Method
}

\author{
I. K. Hindrichsen, ${ }^{* 1}$ M. Kreuzer, ${ }^{*}$ J. Madsen, $\dagger$ and K. E. Bach Knudsen¥ \\ *Institute of Animal Sciences, Swiss Federal Institute of Technology Zurich (ETH), Universitaetstrasse 2, CH-8092 Zurich, Switzerland \\ †Department of Large Animal Sciences, The Royal Veterinary and Agricultural University (KVL), Groennegaardsvej 2, \\ DK-1870 Frederiksberg, Denmark \\ ‡Department of Animal Health, Welfare and Nutrition, Danish Institute of Agricultural Sciences (DJF), PO Box 50, \\ DK-8830 Tjele, Denmark
}

\section{ABSTRACT}

Hemicelluloses, cellulose, and lignin contents of contrasting feeds, with emphasis on concentrate ingredients and complete concentrates, were analyzed using the Van Soest detergent procedure (analyzing neutral detergent fiber, acid detergent fiber, and acid detergent lignin) and the enzymatic-chemical procedure (analyzing cellulose, soluble and insoluble noncellulosic polysaccharides, and Klason lignin). Also, feces from cows fed concentrates differing in carbohydrate composition were analyzed by the 2 procedures. The correlation between acid detergent lignin and Klason lignin was significant, but not as close as the one between individual structural polysaccharides measured with the 2 procedures. The correlation between the results of the 2 procedures was highly significant for apparent cellulose digestibility, as were the correlations between digestibilities of hemicelluloses with total as well as with insoluble noncellulosic polysaccharides. The relationship between dietary lignin content and fiber digestibility was weak. The exclusion of a group of cows fed a concentrate with apple pulp, however, improved the respective correlations. Klason lignin correlated more closely with the measured fiber digestibility than acid detergent lignin. The study showed that results of the detergent method were comparable to those of the enzymatic-chemical method with cellulose, hemicelluloses, and their digestibilities. However, acid detergent lignin was much lower than Klason lignin. When the carbohydrate composition of concentrate varied widely, lignin was not suitable for the prediction of fiber digestibility. Key words: fiber, lignin, method comparison, digestibility

Received June 28, 2005.

Accepted January 4, 2006

${ }^{1}$ Corresponding author: idakh100@hotmail.com

\section{INTRODUCTION}

The fiber fraction makes up an important part of the ruminant diet and originates mainly from plant cell walls that consist of a variety of structural polysaccharides, often cross-linked with proteins and phenolic components, particularly with lignin, which is also prevalent in the cell wall. The main polysaccharides of the plant cell wall are cellulose, various hemicelluloses (e.g., arabinoxylans, $\beta$-glucan, xyloglucans, arabinogalactans), and pectic polysaccharides (e.g., rhamnogalacturonan). The pectin polysaccharides comprise a family of acidic polymers such as homogalacturonans, rhamnogalacturonan, with several neutral polymers such as arabinans, galactans, and arabinogalactans attached to it (Bacic et al., 1988). The noncarbohydrate phenolic polymer lignin can be described as a multibranched network consisting of phenyl propane units. In the cell wall, lignin is partly linked to noncellulosic polysaccharides (NCP), and has 2 main functions. It cements and anchors the cellulosic microfibrils and other matrix polysaccharides and, because the ligninpolysaccharide complex is firm, it stiffens the cell walls, thereby protecting them from degradation and physical damage (Selvendran, 1984).

Various analytical techniques are available for the characterization of the fiber fraction. The oldest and still frequently applied method is the crude fiber (CF) method, which has been in use since the middle of the 19th century (Henneberg and Stohmann, 1859). Because of the substantial solubilization of structural polysaccharides and lignin, this variable only measures an incomplete and variable fraction of the fibrous carbohydrate components. The detergent approach, developed by Van Soest and coworkers for the analysis of fiber-rich forages and currently most frequently applied for fiber analysis in feed (Udén et al., 2005), provides a more satisfactory alternative to better characterize the carbohydrates in the plant cell wall (Van Soest et al., 1991). In this approach, the fractions of the fiber that are insoluble either in neutral detergents or in acid detergent are measured, and the residue after 
treatment of the ADF fraction with $12 \mathrm{~mol} / \mathrm{L}$ sulfuric acid is considered to be acid detergent lignin (ADL). By difference, hemicellulose (NDF - ADF) and cellulose (ADF - ADL) are calculated. However, it has been reported that water-extractable and pectinous polysaccharides are soluble in neutral detergent (Bailey and Ulyatt, 1970; Reichert, 1981; Carre and Brillouet, 1986), and that starch and protein may contaminate the NDF residue (Theander and Åman, 1980). Van Soest et al. (1991) suggested adding $\alpha$-amylase and sodium sulfite to avoid this contamination with starch and protein, respectively. However, the use of sodium sulfite was suggested to be optional, because it also attacks lignin; therefore, it should not be used in sequential analyses leading to lignin determination.

A more recent approach, which requires more sophisticated laboratory equipment, makes use of enzymaticchemical procedures originally developed for a more detailed analysis and characterization of fiber components in food (Asp et al., 1992) and further developed for feed (Southgate, 1995; Bach Knudsen, 1997). The enzymatic-chemical procedure is based on the initial removal of sugars and starch by specific enzymes, the precipitation and recovery of soluble nonstarch polysaccharides (NSP) by 80\% ethanol, and the swelling and hydrolysis of NSP by sulfuric acid. Subsequently, determinations of monomeric constituents are performed either by GLC or HPLC for neutral sugars, by colorimetry for acidic sugars, and by gravimetry for Klason lignin $(\mathbf{K L})$, the insoluble residue. These analytical steps allow one to distinguish between total NSP, cellulose, insoluble and soluble NCP, and KL. Moreover, the monomeric residue of soluble NCP and insoluble NCP provides information about individual sugars including the separation into neutral and acidic sugar monomers. The sum of the individual neutral soluble and insoluble monomers equals hemicellulose.

Most studies in the past comparing methods to determine structural polysaccharides and lignin were focused on forages (e.g., Theander and Westerlund, 1993; Jung et al., 1997, 1999). Only few such analyses have been conducted with concentrates and by-products (Campbell et al., 1997; Miron et al., 2001). In practice, the detergent approach is often used for concentrate feed, even though it was originally developed for analyzing forages. None of the comparisons of methods included actual measurements of digestibilities of the polysaccharide fractions, data that are particularly important for feed evaluation.

The objective of the present investigation was, therefore, to compare the 2 approaches, detergent and enzymatic-chemical analyses, with focus on concentrates and concentrate ingredients, as well as the corresponding feces of dairy cows fed these diverse concentrates.
This study should especially clarify the accuracy of the detergent method when analyzing feeds with a high content of soluble carbohydrates.

\section{MATERIALS AND METHODS}

\section{Diets and Feces}

Included in this study were 18 different concentrate ingredients ( 7 of them from 2 different batches), 6 complete concentrates, 3 different forages ( 2 batches each), and 36 feces samples. The feed samples originated from experiments carried out in vitro (rumen simulation technique; Hindrichsen et al., 2004) and with dairy cows (Hindrichsen et al., 2005a,b). In Table 1, the ingredients and their proportions in the 8 different diets (experimental diets $\mathrm{A}$ to $\mathrm{H}$ ) used in the in vitro experiment are shown. Samples of all individual feed ingredients used in the in vitro experiment and listed in Table 1 were included in the present investigation, except for the coated fat, urea, and sugar beet molasses. Six of these diets (A to F), formulated identically to those compared in vitro, were also tested in vivo by using other batches of the individual diet ingredients. Twelve Brown Swiss dairy cows were fed the diets characterized by the 6 concentrates over 3 experimental periods $(n=6)$. The diets were formulated to meet requirements for maintenance and milk production (about $20 \mathrm{~kg}$ ) of the cows. For the present study, forages, ingredients of the concentrates, complete concentrates mixtures, and feces were sampled and used for chemical analysis and calculation of total digestive tract digestibility.

\section{Analytical Methods}

All analyses were performed in duplicate (CF, NSP, and $\mathrm{KL}$ ) or triplicate (NDF, ADF, and ADL). Before analyses, the feed and feces samples were dried for 48 $\mathrm{h}$ at $60^{\circ} \mathrm{C}$, feed was ground through a $0.5-\mathrm{mm}$ sieve, and feces were ground through a $0.75-\mathrm{mm}$ sieve. The DM content of feed and feces was determined by drying to constant weight at $105^{\circ} \mathrm{C}$, and ash after heating at $550^{\circ} \mathrm{C}$ until a constant weight has been reached (automatically by TGA-500, Leco Corp., St. Joseph, MI). The fiber analyses $(\mathrm{CF}, \mathrm{NDF}$, and $\mathrm{ADF})$ were performed with the Fibertec apparatus (Fibertec System M, Tecator, 1020 Hot Extraction, Flawil, Switzerland). For the $\mathrm{CF}$ analysis, the samples were first treated with $1.25 \%$ sulfuric acid solution (AOAC, 1990; method no. 962.09), followed by a $1.25 \%$ potassium hydroxide solution as suggested by Naumann and Bassler, 1997. Contents of NDF were analyzed with heat-stable $\alpha$-amylase as suggested by Van Soest et al. (1991) and corrected for ash content (i.e., aNDFom according to Udén et al., 2005), but no sodium sulfite was added. Ash-free ADF 
Table 1. Ingredient composition (\% of DM) of the diets with varying concentrate ingredient used in vitro ${ }^{1}$ and in dairy cows ${ }^{2}$

\begin{tabular}{|c|c|c|c|c|c|c|c|c|}
\hline & \multicolumn{8}{|c|}{ Experimental diet } \\
\hline & $\mathrm{A}$ & $\mathrm{B}$ & $\mathrm{C}$ & $\mathrm{D}$ & $\mathrm{E}$ & $\mathrm{F}$ & $\mathrm{G}^{3}$ & $\mathrm{H}^{3}$ \\
\hline \multicolumn{9}{|l|}{ Concentrate ingredients } \\
\hline Wheat & 22.8 & 18.8 & - & - & - & - & - & - \\
\hline Sugar beet molasses & - & 9.2 & - & - & - & - & - & - \\
\hline Jerusalem artichoke & - & - & 33.9 & - & - & - & - & - \\
\hline Soybean hulls & - & - & - & 35.1 & - & - & - & - \\
\hline Oat hulls & - & - & - & - & 25.2 & - & - & - \\
\hline Apple pulp & - & - & - & - & - & 27.1 & - & - \\
\hline Sugar beet pulp & - & - & - & - & - & - & 30.2 & - \\
\hline Guar gum & - & - & - & - & - & - & - & 25.4 \\
\hline Wheat straw meal & 10.6 & 6.1 & 1.7 & - & - & - & 2.8 & 3.3 \\
\hline Oats & - & - & - & 0.8 & 9.9 & 16.4 & 7.2 & 5.0 \\
\hline Grass cubes & 7.9 & 9.9 & 7.4 & 9.0 & - & - & 6.8 & 11.3 \\
\hline Coated fat & 2.8 & 1.5 & - & 2.5 & 4.0 & 0.9 & 2.0 & 0.3 \\
\hline Soybean meal & 5.4 & 4.3 & 6.0 & 2.4 & 10.9 & 5.4 & - & 3.8 \\
\hline Urea & 0.2 & 0.3 & 0.9 & 0.4 & - & 0.6 & 0.9 & 0.9 \\
\hline \multicolumn{9}{|l|}{ Forages } \\
\hline Corn silage & 11.3 & 11.2 & 11.2 & 11.2 & 11.2 & 11.1 & 11.2 & 11.2 \\
\hline Grass silage & 22.5 & 22.3 & 22.4 & 22.3 & 22.4 & 22.2 & 22.5 & 22.4 \\
\hline Hay & 16.5 & 16.4 & 16.5 & 16.4 & 16.4 & 16.3 & 16.5 & 16.4 \\
\hline
\end{tabular}

${ }^{1}$ Hindrichsen et al., 2004.

${ }^{2}$ Hindrichsen et al., 2005a,b.

${ }^{3}$ Not used in the dairy cow experiment.

(ADFom according to Udén et al., 2005) and ADL were determined successively as outlined in AOAC (1990; method no. 973.18, procedures $\mathrm{C}$ and D). For the ADL analysis, the samples were soaked in $12 M$ sulfuric acid for $3 \mathrm{~h}$ and thoroughly washed with boiling distilled water. Ash contents of $\mathrm{CF}, \mathrm{NDF}$, and $\mathrm{ADL}$ were determined by heating for $3 \mathrm{~h}$ at $550^{\circ} \mathrm{C}$ in a muffle furnace. Hemicellulose was calculated as NDF - ADF, and cellulose as ADF - ADL (referred to as cellulose ${ }_{\mathrm{ADF}}$ ).

Total, soluble, and insoluble NSP and their constituent monomeric sugars were determined as alditol acetates by GLC for neutral sugars and by a colorimetric method for uronic acids using a modification of the Englyst et al. (1982) and the Uppsala methods (Theander et al., 1994) as described by Bach Knudsen (1997). This method involves 3 parallel runs (procedures A, B, and C) that principally measure total NSP, total NCP, and insoluble NCP. Klason lignin was measured gravimetrically as the insoluble residue after treating with $12 \mathrm{M}$ sulfuric acid for $1 \mathrm{~h}$ at $35^{\circ} \mathrm{C}$, then diluting with distilled water to $2 M$ sulfuric acid and hydrolyzing for $1 \mathrm{~h}$ at $100^{\circ} \mathrm{C}$ (Theander et al., 1994). Cellulose, referred to as cellulose $_{\mathrm{NSP}}$, was calculated as the difference in $\mathrm{NSP}_{\text {glu- }}$ cose (procedure $\mathrm{A}$ ) and $\mathrm{NCP}_{\text {glucose }}$ (procedure $\mathrm{B}$ ) when the swelling step with $12 M$ sulfuric acid was included (procedure A) or omitted (procedure B). The content of total neutral NCP (t-nNCP) was computed as rhamnose + fucose + arabinose + xylose + mannose + galactose + glucose, and that of soluble neutral NCP (snNCP) as t-nNCP - insoluble neutral NCP (i-nNCP).
Hemicellulose, derived from the detergent method, is assumed pectin free and comparison was therefore done with $\mathrm{t}-\mathrm{nNCP}$. For the calculation of the digestibility coefficients it was further assumed that t-nNCP in feces was equivalent to i-nNCP, because all s-nNCP should have been digested. Digestibilities of dietary i$\mathrm{nNCP}$ and $\mathrm{t}-\mathrm{nNCP}$ were calculated as follows:

$$
\begin{aligned}
& \text { Digestibility of i-nNCP = } \\
& \left(\frac{\mathrm{i}-\mathrm{nNCP}_{\text {diet }}-\mathrm{t}-\mathrm{nNCP}_{\text {feces }}}{\mathrm{i}-\mathrm{nNCP}_{\text {diet }}}\right) \times 100 \text {, } \\
& \text { Digestibility of } \mathrm{t}-\mathrm{nNCP}= \\
& \left(\frac{\mathrm{t}-\mathrm{nNCP}_{\text {diet }}-\mathrm{t}-\mathrm{nNCP}}{\mathrm{t}-\mathrm{nNCP} \mathrm{PP}_{\text {diet }}}\right) \times 100 \text {. }
\end{aligned}
$$

\section{Statistical Analyses}

For the statistical analysis, linear regression analysis was performed to determine the degree of association between the results of the 2 methods applied. The $P$ values refer to a 2 -sided $t$-test of the deviation of the estimated slope from the postulated value of one. For the relationship between lignin data from different analytical procedures (ADL and KL) and in vivo digestibility, ANOVA was performed using the ANOVA protocol from Microsoft Excel XP to calculate the correlation. 
Table 2. Means and variation in fiber and lignin contents (\% of DM) across feed and feces samples as determined by 2 alternative analytical approaches

\begin{tabular}{|c|c|c|c|c|c|c|}
\hline Sample & $\mathrm{n}$ & Mean & $\mathrm{SD}$ & $\mathrm{CV}$ & Minimum & Maximum \\
\hline \multicolumn{7}{|l|}{ Hemicellulose } \\
\hline Concentrate ingredients & 18 & 14.8 & 11.8 & 0.79 & 0.7 & 42.0 \\
\hline Concentrates & 6 & 10.6 & 6.0 & 0.56 & 3.7 & 17.1 \\
\hline Forages & 6 & 17.7 & 3.9 & 0.24 & 13.7 & 24.1 \\
\hline Feces & 35 & 17.9 & 4.7 & 0.26 & 9.7 & 28.1 \\
\hline \multicolumn{7}{|l|}{ Insoluble neutral $\mathrm{NCP}^{2}$} \\
\hline Concentrate ingredients & 18 & 10.5 & 7.6 & 0.73 & 1.5 & 30.8 \\
\hline Concentrates & 6 & 9.6 & 5.7 & 0.59 & 4.3 & 18.6 \\
\hline Forages & 6 & 12.9 & 3.2 & 0.25 & 8.9 & 18.6 \\
\hline \multicolumn{7}{|l|}{ Soluble neutral $\mathrm{NCP}^{2}$} \\
\hline Concentrate ingredients & 18 & 8.0 & 16.0 & 2.01 & 0.9 & 70.9 \\
\hline Concentrates & 6 & 3.6 & 0.9 & 0.26 & 2.4 & 4.9 \\
\hline Forages & 6 & 2.1 & 1.2 & 0.57 & 0.3 & 3.3 \\
\hline \multicolumn{7}{|l|}{ Total neutral $\mathrm{NCP}^{2}$} \\
\hline Concentrate ingredients & 18 & 18.4 & 17.4 & 0.94 & 4.3 & 79.8 \\
\hline Concentrates & 6 & 13.2 & 6.0 & 0.46 & 7.1 & 22.9 \\
\hline Forages & 6 & 14.9 & 3.2 & 0.21 & 11.3 & 19.8 \\
\hline Feces & 35 & 34.5 & 5.9 & 0.17 & 24.9 & 48.1 \\
\hline \multicolumn{7}{|l|}{ Cellulose $_{\mathrm{ADF}}$} \\
\hline Concentrate ingredients & 18 & 17.3 & 15.7 & 0.91 & 0.7 & 49.0 \\
\hline Concentrates & 6 & 17.9 & 7.7 & 0.43 & 6.5 & 26.8 \\
\hline Forages & 6 & 25.3 & 3.7 & 0.15 & 20.6 & 29.5 \\
\hline Feces & 35 & 21.9 & 3.5 & 0.16 & 14.7 & 30.4 \\
\hline \multicolumn{7}{|l|}{ Cellulose $_{\mathrm{NSP}}{ }^{2}$} \\
\hline Concentrate ingredients & 18 & 14.6 & 13.8 & 0.94 & 0.4 & 43.8 \\
\hline Concentrates & 6 & 14.2 & 8.2 & 0.58 & 6.8 & 28.2 \\
\hline Forages & 6 & 20.5 & 3.6 & 0.18 & 16.4 & 25.7 \\
\hline Feces & 35 & 17.5 & 3.1 & 0.18 & 12.2 & 24.4 \\
\hline \multicolumn{7}{|l|}{ Crude fiber } \\
\hline Concentrate ingredients & 18 & 18.9 & 17.4 & 0.92 & 1.4 & 56.9 \\
\hline Concentrates & 6 & 17.4 & 7.5 & 0.43 & 8.4 & 26.2 \\
\hline Forages & 6 & 27.4 & 5.0 & 0.18 & 21.8 & 36.1 \\
\hline Feces & 35 & 27.0 & 2.8 & 0.10 & 22.2 & 35.0 \\
\hline \multicolumn{7}{|l|}{$\mathrm{ADL}^{3}$} \\
\hline Concentrate ingredients & 18 & 4.7 & 4.3 & 0.92 & 0.1 & 12.2 \\
\hline Concentrates & 6 & 4.8 & 3.0 & 0.62 & 1.8 & 10.5 \\
\hline Forages & 6 & 5.2 & 1.9 & 0.36 & 3.4 & 7.9 \\
\hline Feces & 35 & 13.3 & 4.4 & 0.33 & 9.1 & 23.5 \\
\hline \multicolumn{7}{|l|}{ Klason lignin } \\
\hline Concentrate ingredients & 18 & 6.7 & 6.2 & 0.93 & 0.0 & 19.8 \\
\hline Concentrates & 6 & 9.6 & 5.1 & 0.53 & 3.7 & 15.8 \\
\hline Forages & 6 & 9.6 & 2.1 & 0.22 & 6.3 & 12.2 \\
\hline Feces & 35 & 25.0 & 3.4 & 0.14 & 19.5 & 33.3 \\
\hline \multicolumn{7}{|l|}{ Total uronic acids } \\
\hline Concentrate ingredients & 18 & 4.9 & 5.4 & 1.09 & 0.4 & 20.4 \\
\hline Concentrates & 6 & 3.2 & 2.3 & 0.72 & 1.5 & 7.4 \\
\hline Forages & 6 & 3.0 & 1.9 & 0.65 & 0.9 & 5.5 \\
\hline Feces & 35 & 1.4 & 0.3 & 0.22 & 0.9 & 2.1 \\
\hline
\end{tabular}

${ }^{1} \mathrm{NCP}=$ Noncellulosic polysaccharides.

${ }^{2} \mathrm{NSP}=$ Nonstarch polysaccharides.

${ }^{3} \mathrm{ADL}=$ Acid detergent lignin.

\section{RESULTS}

The comparisons between the detergent or the enzymatic-chemical methods for measuring fiber and lignin were done by calculating linear regressions. The linear regressions for feed and the feces were calculated separately, but shown in the same figure to permit easier comparison of the different groups.

Table 2 shows the variation in the contents of cell wall constituents as determined by the detergent and the enzymatic-chemical approach for feeds (concentrate ingredients, complete concentrates, and forages) and feces. Among concentrate ingredients, the largest variation was present in the hemicellulose content, ranging from $0.7 \%$ (Jerusalem artichoke tubers) to $42 \%$ (oat hulls). The average of $t$-nNCP measured was nearly twice as high, mainly because a variable proportion of soluble components, i.e., galactomannans from guar gum, were recovered in the s-nNCP fraction. Concerning cellulose measured with the detergent and the enzy- 


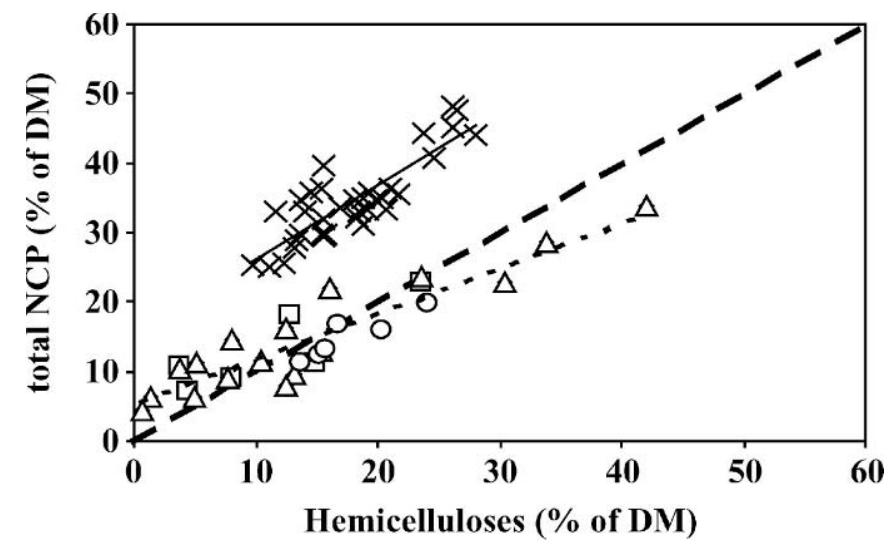

Figure 1. Linear regressions of total neutral noncellulosic polysaccharides (total NCP) on hemicelluloses contents for feed [forages $(\bigcirc)$, concentrate ingredients $(\triangle)$, complete concentrates $(\square) ; \mathrm{y}(----)=0.65 \mathrm{x}$ $\left.+5.14 ; P<0.001 ; \mathrm{R}^{2}=0.829 ; \mathrm{n}=29\right]$ and feces $[\mathrm{x} ; \mathrm{y}(-)=1.06 \mathrm{x}$ $\left.+15.44 ; P>0.05 ; \mathrm{R}^{2}=0.726 ; \mathrm{n}=35\right]$. The dashed line $(---)$ represents the line of equality. Coefficient of determination across all data $=0.424$.

matic-chemical procedures, the concentrate ingredients again presented the largest variation, ranging from 0.7 to $49.0 \%$ for cellulose $\mathrm{ADF}_{\mathrm{A}}$ and 0.4 to $43.8 \%$ for cellulose $_{\text {NSP. }}$ The CF content across all feeds ranged between 1.4 and $56.9 \%$ in DM; the ADL contents ranged from 0.1 to $12.2 \%$, and $\mathrm{KL}$ contents ranged from 0.0 to $19.8 \%$. The corresponding variations in feces were 9.1 to $23.5 \%$ for ADL and 19.5 to $33.3 \%$ for KL. The contents of total uronic acids, widely equivalent to pectins, varied between 0.4 and $20.4 \%$ in concentrate ingredients, whereas the feces samples only contained between 0.9 to $2.1 \%$ total uronic acids. There were substantial differences between different batches of the same concentrate ingredient (e.g., oat hulls). A difference in the magnitude of up to a factor of 3 was found in hemicellulose content and a factor of 10 in cellulose $\mathrm{ADF}_{\mathrm{A}}$ (data not shown in table). These differences were not artifacts, as they could be confirmed by the enzymatic-chemical approach.

The correlation between hemicellulose and t-nNCP across all samples was 0.66 . As can be seen from Figure 1 , the feces t-nNCP content was substantially higher than the hemicelluloses content measured with the detergent method, but the coefficient of regression $\left(R^{2}=\right.$ 0.726 ) was close and the slope was nonsignificantly different $(P>0.05)$. Guar gum had a very high content of s-nNCP $(88.8 \%)$ of which only $35 \%$ was attributed to the hemicellulose fraction by the detergent method, resulting in a low coefficient of regression $(\mathrm{y}=0.87 \mathrm{x}+$ $\left.3.96, \mathrm{R}^{2}=0.386, P>0.05 ; \mathrm{n}=30\right)$. When excluding guar gum from the regression analysis, the coefficient of regression between hemicellulose and $\mathrm{t}$-nNCP in feed was even improved $\left(\mathrm{y}=0.65 \mathrm{x}+5.14, \mathrm{R}^{2}=0.829, P<\right.$

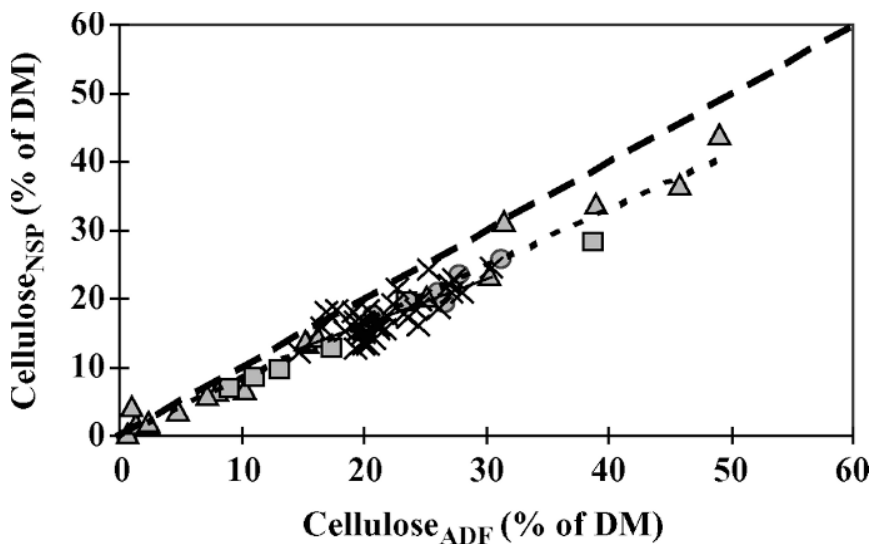

Figure 2. Linear regressions of the contents of cellulose as determined by the enzymatic-chemical method on that determined by the detergent method for feed [forages $(\bigcirc)$, concentrate ingredients $(\triangle)$, complete concentrates $(\square)$; y $(---)=0.83 \mathrm{x}-0.079 ; P<0.001 ; \mathrm{R}^{2}=$ $0.975 ; \mathrm{n}=30]$ and feces $\left[\mathrm{x} ; \mathrm{y}(-)=0.66 \mathrm{x}+3.07 ; P<0.001 ; \mathrm{R}^{2}=\right.$ $0.558 ; \mathrm{n}=35]$. The dashed line $(-\ldots-)$ represents the line of equality. Coefficient of determination across all data $=0.938$.

$0.001 ; \mathrm{n}=29)$, but the estimated slope was significantly different from the postulated slope.

The contents (\% of DM) of cellulose in feed and feces as determined by the detergent (cellulose $\left.{ }_{\mathrm{ADF}} ; \mathrm{x}\right)$ and the enzymatic-chemical method (cellulose $\mathrm{NSP}_{\mathrm{N}} ; \mathrm{y}$ ) were closely related overall $\left(\mathrm{y}=0.84 \mathrm{x}-0.68 ; \mathrm{R}^{2}=0.922, P\right.$ $<0.001 ; \mathrm{n}=65$ ). Relationships were close as well within feeds $\left(\mathrm{y}=0.83 \mathrm{x}+0.079, \mathrm{R}^{2}=0.975, P<0.001 ; \mathrm{n}=30\right)$ and feces $\left(\mathrm{y}=0.66 \mathrm{x}+3.07, \mathrm{R}^{2}=0.558, P<0.01 ; \mathrm{n}=\right.$ 35 ) when calculated separately, but the estimated slope was significantly different from the postulated value of 1 (Figure 2). Overall, estimates of cellulose contents of both feed and feces were slightly higher with the detergent method than with the enzymatic-chemical approach and both slopes were significantly different. Content (\% of DM) of CF (y) also correlated well with cellulose $_{\mathrm{ADF}}$ contents $\left(\mathrm{y}=1.02 \mathrm{x}+3.06 ; \mathrm{R}^{2}=0.878 ; P>\right.$ $0.05 ; \mathrm{n}=65$ ). The slope was close to one and nonsignificantly different. Cellulose ${ }_{\mathrm{NSP}}\left(\mathrm{y}=1.20 \mathrm{x}+4.02 ; \mathrm{R}^{2}=\right.$ $0.856 ; P<0.01 ; \mathrm{n}=65$ ) was also strongly correlated, but the slope was significantly different (not shown in figure).

The correlation between ADL and KL across a total of 65 samples (feed and feces) was 0.87 (Figure 3). In the feed samples alone, this correlation was 0.83 ; it was only 0.65 in feces, mainly due to 2 outliers. The slope of the feces samples was also significantly different $(P$ $<0.001$ ), and the slope of the feed samples was nonsignificantly different $(P>0.05)$. Feces of cows fed the apple pulp diet had higher lignin content when measured both as ADL and KL compared with feces of cows fed the other 5 diets. 


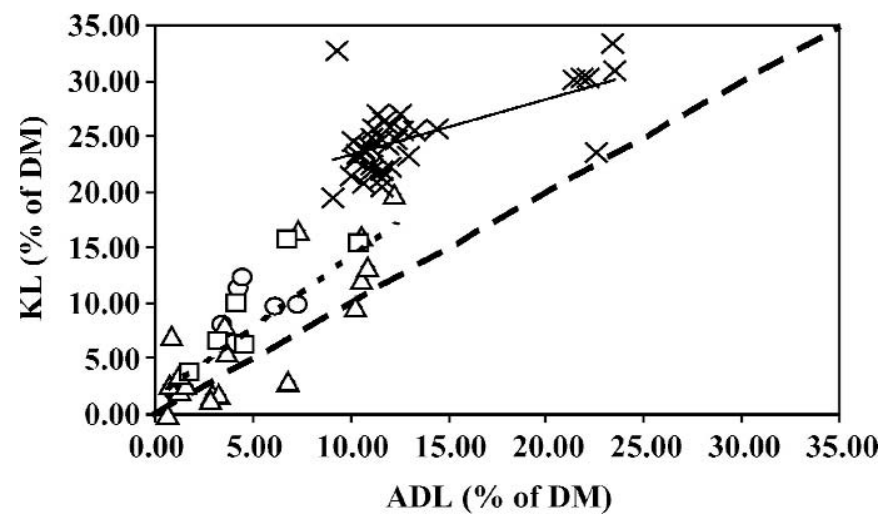

Figure 3. Linear regressions of contents of Klason lignin (KL) on acid detergent lignin (ADL) for feed [forages $(\bigcirc)$, concentrate ingredients $(\triangle)$, complete concentrates $(\square)$; y $(---)=1.30 \mathrm{x}+1.29 ; P>0.05$; $\left.\mathrm{R}^{2}=0.691 ; \mathrm{n}=30\right]$ and feces $[\times ; \mathrm{y}(-)=0.50 \mathrm{x}+18.37 ; P<0.001$; $\left.\mathrm{R}^{2}=0.418 ; \mathrm{n}=35\right]$. The dashed line $(--\ldots)$ represents the line of equality. Coefficient of determination across all data $=0.742$.

The comparisons in digestibility of the dairy cows were based on either cellulose or hemicellulose measured with the 2 respectively differing approaches are shown in Figure 4 . The 2 differently determined coefficients of cellulose digestibility had a close correlation and the slope was nonsignificantly different $(\mathrm{y}=1.03 \mathrm{x}$ - 6.61; $\mathrm{R}^{2}=0.792 ; P>0.05 ; \mathrm{n}=35$ ). The correlation between the hemicellulose digestibility (detergent method) and the digestibility of i-nNCD and t-nNCP was 0.87 and 0.86 , respectively. The slope of i-nNCP was nonsignificantly $(P>0.05)$ different, and t-nNCP was significantly $(P>0.001)$ different.

The relationships between ADL content of the feed $\mathrm{DM}$ as consumed by the cows and the actual digestibilities of OM, hemicellulose, i-nNCP, t-nNCP, cellulose $_{\mathrm{ADF}}$, and cellulose $\mathrm{NSP}_{\mathrm{NP}}$ were very weak, with correlations of $0.44,0.08,0.04,0.14,0.08$, and 0.17 , respectively. The corresponding correlations to KL were only slightly higher with $0.65,0.19,0.38,0.27,0.31$, and 0.16 , respectively. The apple pulp diet had a high lignin content (ADL and $\mathrm{KL}$ ), but this did not impair digestibility noticeably compared with the other diets. Excluding this experimental group increased the coefficient of determination markedly (Table 3 ).

\section{DISCUSSION}

\section{Contents and Digestibilities of Fiber as Determined by Different Analytical Approaches}

Total nNCP obtained with the enzymatic-chemical method would have been expected to be closely related to the hemicelluloses as calculated from the difference of the detergent fractions NDF and ADF. Indeed, there

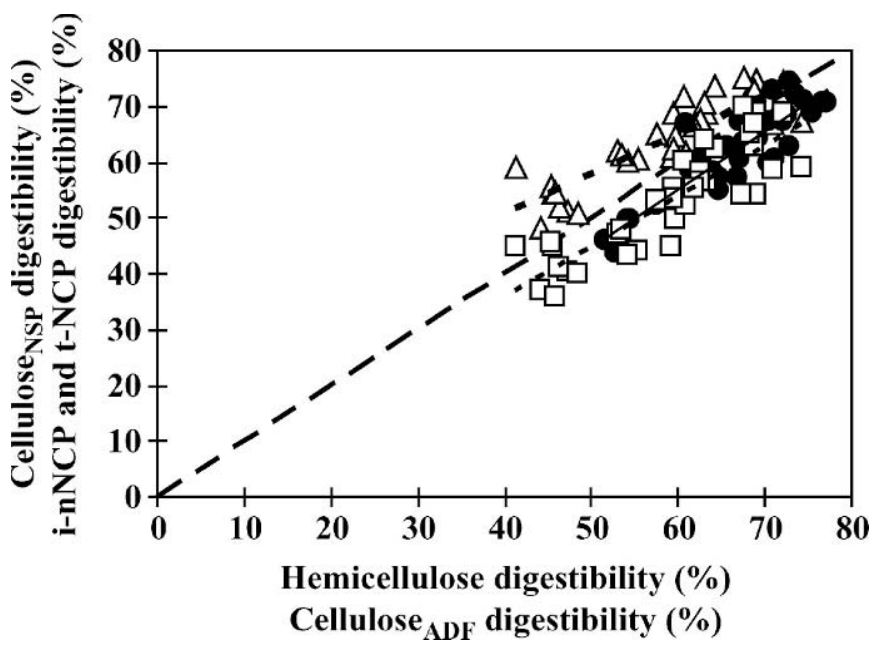

Figure 4. Linear regressions of cellulose digestibility as determined with the enzymatic-chemical method (y axis) on the detergent procedure ( $\mathrm{x}$ axis) $\left[0 ; \mathrm{y}(-)=1.03 \mathrm{x}-6.61 ; P>0.05 ; \mathrm{R}^{2}=0.792\right.$; $\mathrm{n}=35$ ], of insoluble neutral noncellulosic polysaccharides (i-nNCP) digestibility on hemicelluloses digestibility $[\square ; \mathrm{y}(---)=0.91 \mathrm{x}-0.63$; $P>0.05 ; \mathrm{R}^{2}=0.750 ; \mathrm{n}=35$ ], and total neutral noncellulosic polysaccharides (t-nNCP) digestibility on hemicelluloses digestibility $[\Delta ; \mathrm{y}$ $\left.(-)=0.71 \mathrm{x}+22.15 ; P<0.001 ; \mathrm{R}^{2}=0.741 ; \mathrm{n}=35\right]$. The dashed line ( $-\ldots)$ represents the line of equality.

was a close correlation between the results of the 2 methods, but the detergent method provided substantially lower hemicellulose estimates in the feed samples. Although the probably underestimated lignin contents, when determined as ADL, would have even increased the hemicellulose estimate, the low hemicellulose contents indicate that a certain percentage of soluble hemicellulose might have been dissolved in neutral detergent solution. This is particularly obvious from the analysis of guar gum, containing a high amount of soluble hemicelluloses, where only about $30 \%$ of $\mathrm{t}$-nNCP was detected by the detergent method as hemicelluloses; this was also observed by Campbell et al. (1997). However, measuring hemicellulose content in the feces by the detergent method, in which no significant amounts of residual soluble hemicelluloses are expected, still resulted in lower hemicellulose contents than t-nNCP values in all samples. The s-nNCP was not measured in feces; the authors found no other studies comparing the 2 methods in feces samples. It is therefore not possible to give a feasible answer for the difference between $\mathrm{t}$-nNCP and hemicellulose in feces.

For the kind of samples analyzed in the present study, the correlation between cellulose $\mathrm{ADF}_{\mathrm{AD}}$ and cellulose $_{\text {NSP }}$ was high compared with what was found for lignin, and the absolute levels were close. Any analytical errors that may arise with ADL are similarly accounted for in $\mathrm{ADF}$ with cellulose representing the difference between the 2 fractions. Similar to the feeds, the 
Table 3. Linear regressions of dietary contents of acid detergent lignin and Klason lignin (\% of DM) and digestibility (\%) of various fiber fractions, including and excluding data of the apple-pulp containing diet

\begin{tabular}{|c|c|c|}
\hline & Acid detergent lignin & Klason lignin \\
\hline $\mathrm{OM}$ & $\mathrm{y}=-3.5 \mathrm{x}+83.6 ; P<0.01 ; \mathrm{R}^{2}=0.193$ & $\mathrm{y}=-1.5 \mathrm{x}+84.4 ; P=0.001 ; \mathrm{R}^{2}=0.429$ \\
\hline Hemicelluloses & $\mathrm{y}=0.5 \mathrm{x}+56.9 ; P=0.666 ; \mathrm{R}^{2}=0.006$ & $\mathrm{y}=-0.7 \mathrm{x}+66.7 ; P=0.282 ; \mathrm{R}^{2}=0.035$ \\
\hline t-nNCP ${ }^{2}$ & $\mathrm{y}=0.7 \mathrm{x}+60.7 ; P=0.429 ; \mathrm{R}^{2}=0.019$ & $\mathrm{y}=-0.9 \mathrm{x}+73.1 ; P=0.120 ; \mathrm{R}^{2}=0.072$ \\
\hline Cellulose $_{\mathrm{ADF}}$ & $\mathrm{y}=0.4 \mathrm{x}+64.8 ; P=0.654 ; \mathrm{R}^{2}=0.006$ & $\mathrm{y}=-0.9 \mathrm{x}+76.3 ; P=0.075 ; \mathrm{R}^{2}=0.093$ \\
\hline Cellulose $_{\mathrm{NSP}}{ }^{3}$ & $\mathrm{y}=1.0 \mathrm{x}+57.5 ; P=0.338 ; \mathrm{R}^{2}=0.028$ & $\mathrm{y}=-0.6 \mathrm{x}+68.1 ; P=0.345 ; \mathrm{R}^{2}=0.027$ \\
\hline Hemicelluloses & $\mathrm{y}=-2.6 \mathrm{x}+69.2 ; P>0.05 ; \mathrm{R}^{2}=0.057$ & $\mathrm{y}=-1.9 \mathrm{x}+76.4 ; P<0.05 ; \mathrm{R}^{2}=0.174$ \\
\hline i-nNCP & $\mathrm{y}=-4.5 \mathrm{x}+72.8 ; P<0.05 ; \mathrm{R}^{2}=0.134$ & $\mathrm{y}=-3.0 \mathrm{x}+83.1 ; P<0.001 ; \mathrm{R}^{2}=0.358$ \\
\hline t-nNCP & $\mathrm{y}=-3.4 \mathrm{x}+77.1 ; P<0.05 ; \mathrm{R}^{2}=0.155$ & $\mathrm{y}=-2.3 \mathrm{x}+85.5 ; P<0.001 ; \mathrm{R}^{2}=0.433$ \\
\hline Cellulose $_{\mathrm{ADF}}$ & $\mathrm{y}=-4.5 \mathrm{x}+84.0 ; P<0.01 ; \mathrm{R}^{2}=0.303$ & $\mathrm{y}=-2.4 \mathrm{x}+89.0 ; P<0.001 ; \mathrm{R}^{2}=0.542$ \\
\hline Cellulose $_{\mathrm{NSP}}$ & $\mathrm{y}=-4.3 \mathrm{x}+78.2 ; P<0.05 ; \mathrm{R}^{2}=0.220$ & $\mathrm{y}=-2.2 \mathrm{x}+82.0 ; P<0.001 ; \mathrm{R}^{2}=0.360$ \\
\hline
\end{tabular}

$1_{\text {i-nNCP }}=$ Insoluble neutral noncellulose polysaccharides.

${ }^{2} \mathrm{t}-\mathrm{nNCP}=$ Total neutral noncellulose polysaccharides.

${ }^{3} \mathrm{NSP}=$ Nonstarch polysaccharides.

cellulose digestibilities as determined by the detergent method seem to be quite reliable because the values were close to line of equality when related to the enzymatic-chemically derived data.

In feeds and feces analyzed in the present study, a close correlation was found between $\mathrm{CF}$ and cellulose $_{\mathrm{ADF}}$ as well as cellulose $\mathrm{NSP}_{\mathrm{NS}}$. The CF analysis based on the Weende method (Henneberg and Stohmann, 1859) was the first established method of fiber analysis, but has been superseded by the detergent method (Udén et al., 2005) because NCP and part of the lignin are dissolved along with the $\mathrm{CF}$ analysis procedure (Theander and Westerlund, 1993). Nevertheless, several countries still use CF data in feed tables.

The relationships between fiber digestibilities calculated from results of the detergent and the enzymaticchemical method were close to the line of equality and, therefore, considered reliable. This was also concluded in a study with rabbits, in which NSP digestibility was positively correlated with the difference of NDF and ADL (Garcia et al., 1999).

\section{Lignin Contents as Determined by Different Analytical Approaches}

A key difficulty in the evaluation of the fiber in feeds is the quantification of lignification of fibrous carbohydrates, which largely determines digestibility and use. Lignin is very difficult to analyze accurately because it is insoluble and therefore cannot be determined directly with any specific procedure. In the present study, contents of $\mathrm{KL}$ were higher than that of $\mathrm{ADL}$, apart from a few exceptions where the lignin content was very low. In an earlier study, KL was found to be 2 to 5 times higher than ADL (Hatfield et al., 1994). Van Soest
(1967) and Lai and Sarkanen (1971) speculated on whether the higher content of KL compared with ADL could be due to contamination with protein when applying the KL method, which was originally developed for wood analysis. Kondo et al. (1987) and Lowry et al. (1994), on the other hand, showed that acid soluble lignin is lost during the acid detergent step, and Hatfield et al. (1994) confirmed that KL was neither significantly contaminated with protein nor with carbohydrates, and that the molecular composition was similar to that found in the ADL fraction. Furthermore, Jung et al. (1999) found that with the KL analysis the percentage of gross energy based on the calculation from the composition accounted for 85 to $97 \%$ of the measured gross energy, whereas the gross energy calculated based on ADL only accounted for 68 to $84 \%$ of the measured gross energy. This illustrates that there was no contamination of either protein or carbohydrate in $\mathrm{KL}$; otherwise, values would have exceeded $100 \%$. It seems likely that the acid detergent method dissolves a greater part of the lignin than occurs with the KL procedure. Even though the KL method also yielded values in the present investigation that were higher than ADL values (especially when measuring feces), there was a close and positive correlation between the results of the 2 methods $\left(\mathrm{R}^{2}=0.74, P<0.001\right)$. This is in line with earlier studies comparing different kinds of forages (Hatfield et al., 1994; Jung et al., 1997, 1999), whereas other investigations comparing sodium chlorite lignin and permanganate lignin in 15 different samples showed only a correlation of 0.54 (Collings et al., 1978), indicating that not all lignin determination methods are equally well correlated. 


\section{Lignin as an Indicator for Fiber Digestibility}

Analyzing the lignin content of feed is often considered an easy method to estimate fiber digestibility, particularly in forage, because lignin is known for its adverse effect on digestibility, due to the presence of crosslinks between lignin and the cell wall polysaccharides (Jung et al., 1997). Because the extent of these crosslinks varies, there are limitations to this approach, and the ideal analytical method for lignin is still to be found (see above). For instance, the apple pulp diet differed very much from the other diets in its relationship between dietary lignin content and fiber digestibility, and its exclusion from the data set improved the accuracy of the estimate markedly. This illustrates that particularly apple pulp lignin and the corresponding digestive properties deviated from that of all others. Apple pulp has astonishingly high contents of lignin of 14 to $18 \%$ (Singh and Narang, 1992; NRC, 2001), which corresponds to the 10 and $19 \% \mathrm{KL}$ found in the 2 batches analyzed in the present study. From pear pulp it is known that the high lignin content of the pulp might result from significant amounts of lignin contained in the seeds (Menke and Huus, 1987). Whether this was also the case with the batches of apple pulp is not known. Nevertheless, the high lignin content in the apple pulp diet did not seem to have the same negative effect on fiber digestibility as the oat hulls diet. There is a possibility that cutins may influence the lignin determinations in apple pulp, and because cutins are resistant to bacterial degradation, cutinized tissues may serve an important role in restricting access of bacteria (and bacteria enzymes) to the cell wall polysaccharides of some vegetables and fruits. However, to confirm this assumption, the digestibility of apple pulp would need to be scrutinized in further detail. Singh and Narang (1992) observed a high fiber digestibility in male calves fed wheat straw supplemented either with apple pulp and urea or a conventionally composed supplement (30\% groundnut meal and corn, $36 \%$ wheat bran, $2 \%$ mineral mixture, and common salt), even though apple pulp contained more lignin than the conventional supplement. The authors suggested that the nature of the cross-linkages of lignin with the polysaccharides in apple pulp is different compared with other feed and is less inhibitory to digestion. The relationship between lignin and fiber digestibility seems to be more reliable when comparing different types of forages than of concentrate ingredients. By investigating 36 forages, Jung et al. (1997) showed that ADL and KL were similarly related to the digestibility of the forage, even though the KL procedure again yielded higher lignin values compared with ADL. This required different linear regression equations but did not affect the accuracy of the prediction of digestibility. The authors concluded from this observation that the lignin, undetected by the ADL procedure, has an effect on fiber digestibility that is comparable to that of the proportion of lignin actually detected.

\section{CONCLUSIONS}

According to this study, the detergent method and the enzymatic-chemical method are equivalent with respect to data related to cellulose and, for the most part, hemicellulose. However, soluble hemicellulose in concentrate was only partly detected by the detergent procedure, and the procedure is therefore not suitable for all kinds of concentrates. Weaknesses were found for $\mathrm{ADL}$ as a measure for lignin and for both $\mathrm{ADL}$ and $\mathrm{KL}$ as an indicator of fiber digestibility in comparisons where the major variations occur in concentrates and where ingredients with high amounts of soluble hemicellulose (e.g., guar gum galactomannans) or with an uneven lignin distribution and association with fiber (apple pulp) are used. The low accuracy of dietary lignin in concentrate-dominated diets to predict fiber digestibility was unexpected compared with existing reports, which are based mainly on forage-dominated diets. The results, therefore, suggest that lignin is only a reliable indicator of fiber digestibility in diets in which the dietary lignin content is mainly supplied by the forage.

\section{ACKNOWLEDGMENTS}

The first author is grateful to Danish Research Agency for providing a scholarship. We would also like to thank the technical staff at DJF and ETH for the excellent introduction to the laboratory work.

\section{REFERENCES}

Asp, N.-G., T. F. Schweizer, D. A. T. Southgate, and O. Theander. 1992. Dietary fibre analysis. Pages 57-102 in Dietary Fibre - A Component of Food: Nutritional Function in Health and Disease. T. F. Schweizer and C. A. Edwards, ed. Springer Verlag, London, UK.

AOAC. 1990. Official Methods of Analysis. 15th ed. Association of Official Analytical Chemists, Arlington, VA.

Bach Knudsen, K. E. 1997. Carbohydrate and lignin contents of plant materials used in animal feeding. Anim. Feed Sci. Technol. 67:319-338.

Bacic, A., P. J. Harris, and B. A. Stone. 1988. Structure and function of plant cell walls. Pages 297-371 in The Biochemistry of Plants. J. Preiss, ed. Academic Press, New York, NY.

Bailey, R. W., and M. J. Ulyatt. 1970. Pasture quality and ruminant nutrition. II Carbohydrate and lignin composition of detergent extracted residues from pasture grasses and legumes. N.Z. J. Agric. Res. 13:591-604.

Campbell, J. M., E. A. Flickinger, and G. C. Jr. Fahey. 1997. A comparative study of dietary fiber methodologies using pulsed electrochemical detection of monosaccharide constituents. Sem. Food Anal. 2:43-53. 
Carre, B., and J. M. Brillouet. 1986. Yield and composition of cell wall residues isolated from various feedstuffs used for non-ruminant farm animals. J. Sci. Food Agric. 37:341-351.

Collings, G. F., M. T. Yokoyama, and W. G. Bergen. 1978. Lignin as determined by oxidation with sodium chlorite and a comparison with permanganate lignin. J. Dairy Sci. 61:1156-1160.

Englyst, H. N., H. S. Wiggins, and J. H. Cummings. 1982. Determination of the non-starch polysaccharides in plant foods by gas-liquid chromatography of constituent sugars as the alditol acetales. Analyst 107:307-318.

Garcia, J., R. Carabaño, and J. C. de Blas. 1999. Effect of fiber source on cell wall digestibility and rate of passage in rabbits. J. Anim. Sci. 77:898-905.

Hatfield, R. D., H. G. Jung, J. Ralph, D. R. Buxton, and P. J. A Weimer. 1994. A comparison of the insoluble residues produced by the Klason lignin and acid detergent lignin procedures. J. Sci. Food Agric. 65:51-58.

Henneberg, W., and F. Stohmann. 1859. Über das Erhaltungsfutter volljährigen Rindviehs. J. Landwirtsch. 3:485-551.

Hindrichsen, I. K., H.-R. Wettstein, A. Machmüller, C. R. Soliva, K. E. Bach Knudsen, J. Madsen, and M. Kreuzer. 2004. Effects of feed carbohydrates with contrasting properties on rumen fermentation and methane release in vitro. Can. J. Anim. Sci. 84:265276.

Hindrichsen, I. K., H.-R. Wettstein, A. Machmüller, K. E. Bach Knudsen, J. Madsen, and M. Kreuzer. 2005a. Digestive and metabolic utilisation of dairy cows supplemented with concentrates characterised by different carbohydrates. Anim. Feed Sci. Technol. 126:43-51.

Hindrichsen, I. K., H.-R. Wettstein, A. Machmüller, B. Jörg, and M. Kreuzer. 2005b. Effect of the carbohydrate composition of feed concentrates on methane emission from dairy cows and their slurry. Environ. Monit. Assess. 107:329-350.

Jung, H. G., D. R. Mertens, and A. J. Payne. 1997. Correlation of acid detergent lignin and Klason lignin with digestibility of forage dry matter and neutral detergent fiber. J. Dairy Sci. 80:16221628.

Jung, H. G., V. H. Varel, P. J. Weimer, and J. Ralph. 1999. Accuracy of Klason lignin and acid detergent lignin methods as assessed by bomb calorimetry. J. Agric. Food Chem. 47:2005-2008.

Kondo, T., K. Mizuno, and T. Kato. 1987. Variation in solubilities of lignin in acid detergent and in alkali. J. Jpn. Grassl. Sci. 33:296-299

Lai, Y. Z., and K. V. Sarkanen. 1971. Isolation and structural studies. Pages 165-230 in Lignins: Occurrence, Formation, Structure and
Reactions. K. V. Sarkanen and C. H. Ludwig, ed. Wiley Interscience, New York, NY.

Lowry, J. B., L. L. Conlan, A. C. Schlink, and C. S. McSweeney. 1994. Acid detergent dispersible lignin in tropical grasses. J. Sci. Food Agric. 65:41-49.

Naumann, K., and R. Bassler. 1997. Die chemische Untersuchung von Futtermitteln. Vol. 3. VDLUFA-Verlag, Darmstadt, Germany.

Menke, K.-H., and W. Huus. 1987. Tierernährung und Futtermittelkunde. 2nd ed. Ulmer Verlag, Stuttgart, Germany.

Miron, J., E. Yosef, and D. Ben-Ghedalia. 2001. Composition and in vitro digestibility of monosaccharide constituents of selected byproduct feeds. J. Agric. Food Chem. 49:2322-2326.

National Research Council. 2001. Nutrient Requirements of Dairy Cattle: 7th rev. ed. Natl. Acad. Press, Washington, DC.

Reichert, R. D. 1981. Quantitative isolation and estimation of cell wall materials from dehulled pea (Pisum sativum) flours and concentrates. Cereal Chem. 58:266-270.

Selvendran, R. R. 1984. The plant cell wall as a source of dietary fiber: Chemistry and structure. Am. J. Clin. Nutr. 39:320-337.

Singh, B., and M. P. Narang. 1992. Studies on the rumen degradation kinetics and utilization of apple pomace. Bioresour. Technol. 39:233-240.

Southgate, D. A. T. 1995. Dietary Fibre Analysis. Royal Society of Chemistry, Food Analysis Monographs, Cambridge, UK.

Theander, O., and P. Aman. 1980. Chemical composition of some forages and various residues from feeding value determinations. J. Sci. Food Agric. 31:31-37.

Theander, O., and E. Westerlund. 1993. Quantitative analysis of cell wall components. Pages $83-104$ in Forage Cell Wall Structure and Digestibility. H. G. Jung, D. R. Buxton, R. D. Hatfield, and J. Ralph, ed. American Society of Agronomy, Inc., Madison, WI.

Theander, O., P. Aman, E. Westerlund, and H. Graham. 1994. Enzymatic/chemical analysis of dietary fiber. J. AOAC Int. 77:703-709.

Udén, P., P. H. Robinson, and J. Wiseman. 2005. Use of detergent system terminology and criteria for submission of manuscripts on new, or revised, analytical methods as well as descriptive information on feed analysis and/or variability. Anim. Feed Sci. Technol. 118:181-186.

Van Soest, P. J. 1967. Development of a comprehensive system of feed analysis and its application to forages. J. Anim. Sci. 26:119-128.

Van Soest, P. J., J. B. Robertson, and B. A. Lewis. 1991. Methods for dietary fiber, neutral detergent fiber, and nonstarch polysaccharides in relation to animal nutrition. J. Dairy Sci. 74:35833597. 